\title{
Darwin and American public administration Woodrow Wilson's Darwinian argument for administration
}

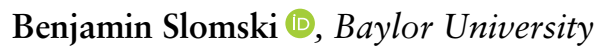

AвSTRACT. This research note addresses a gap in the public administration literature by arguing that a political Darwinism was present in the intellectual origins of American administrative theory. By examining the arguments of Woodrow Wilson, this article demonstrates that Darwinism complemented the German political thought that contributed to the establishment of America's administrative state. The application of Darwinian evolutionary biology to politics was a vital element of Wilson's reconceptualization of the state as a living organism. Darwinism was a key rhetorical tool employed by Wilson in his argument against the Constitution's separation of powers. This note finds that Darwinism was present in the early stages of public administration theory in Wilson's argumentation and persists today in the public administration literature. It concludes by sketching out an agenda for further research on Darwinism's influence on public administration.

Key words: Darwin, Darwinism, public administration theory, Woodrow Wilson, separation of powers

I $\mathrm{n}$ recent decades, public administration literature has featured much work on the importance of ideas in shaping administration (Adams, 1992; Durant \& Rosenbloom, 2017; Kettl, 2000; Spicer, 2004b). In this regard, recent work has focused on the relation between political theory and public administration. There has been a special focus on the influence that German political thinkers, especially G. W. F. Hegel and Max Weber, had on public administration (Gale \& Hummel, 2003; Liebich, 1982; Shaw, 1992; Spicer, 2004a; Tijsterman \& Overeem, 2008). Scholarship on the intellectual origins of the American administrative state has traced the influence of German thought on Woodrow Wilson, Frank Goodnow, and other early proponents of the study of public administration (Rosser, 2010, 2012; Sager \& Rosser, 2009; Seibel, 2010). In contrast, Charles Darwin and the various strands of social and political Darwinism that he inspired have been absent from these accounts. Scholars in history and economics have occasionally recognized the Darwinist influence on the development of American public administration (Harris, 2016; Leonard, 2016; Moreno, 2013), but the public administration field lacks its own account of this movement.

doi: $10.1017 /$ pls.2021.24

Correspondence Benjamin Slomski, Baylor University, Department of Political Science, Waco, Texas. Email: Ben_Slomski@baylor.edu
This article begins to address that gap by examining Darwinism as a source of the conscious development of American public administration. There has been much research applying Darwinism and biology to the study of public administration, but a gap persists when it comes to the relevance of Darwinism in the early intellectual development of public administration as a self-conscious discipline. This research note focuses on Woodrow Wilson's argument for administration, as Wilson was a prominent figure in the early development of American public administration and often cast as the exemplar of German influence on administrative theory. Even in Wilson's thought, Darwinian arguments were present. Wilson's administrative theory centered on an intentional rejection of the constitutional separation of powers. The political application of Darwinian evolutionary biology was a core element of this rejection in Wilson's rhetoric.

To be clear, a variety of intellectual sources contributed to the new theories of administration that marked the late nineteenth and early twentieth centuries, especially German political thought. Darwinism complemented these other theories, and a full account of the intellectual origins of American public administration should not exclude it. Hegel and Weber emphasized the need for rational and efficient bureaucracy that fit the progressive evolution of history. By providing supposed scientific authority rooted in biology to affirm the organic and evolving nature of society, Darwinism 


\section{Benjamin Slomski}

supplemented German thought. Darwinism also offered greater rhetorical potential than German thought as Wilson and others sought to put new administrative theories into practice. As a prevalent theory during the Progressive era with a claim to scientific legitimacy, Darwinism offered a rhetorical device that was more accessible than German philosophy and its convoluted terminology. As popular rhetorical leadership was a vital element of Wilson's unified administrative state, the persuasive appeal of Darwinism would make it a key element of his argument against the separation of powers.

Before turning to Wilson's arguments, a preliminary clarification is needed. This study uses the term Darwinism to refer to the application of Charles Darwin's scientific theories to political and social life. Darwinism is a move beyond Darwin's findings to an ideological theory. Social Darwinism is often conflated with the individualistic strain associated with William Graham Sumner that favored a greatly restricted government. Darwinism, however, was adopted by political leaders of all persuasions to justify their positions (Leonard, 2009).

The Darwinian movement began with Charles Darwin's insight that the variations in traits most advantageous for surviving the struggle against existence will reproduce themselves over time, leading to a process of natural selection and evolution of species (Darwin, 1859/ 1928). Whether Darwin himself would have accepted any form of social or political Darwinism is an open question that cannot be settled by this study. Ambiguities in Darwin's writings allowed his theory to be appropriated by diverse political sects for their causes (Paul, 2009). Darwinian evolutionary biology introduced a historically oriented science that contrasts with the normal methods of other sciences, such as physics, that focus on fixed phenomena (Mayr, 2000). This historically oriented approach replaced a fixed nature with a contingent one and offered political applications that would be invoked by partisans of all sides. As Leonard (2016) explains, there was "something in Darwin for everyone," as evolutionary theories were used to defend an array of conservative and liberal positions (p. 90).

A strain of Darwinism emerged that was influential for the Progressive reformers who defended the administrative state. Progressive Darwinists tended to reject natural selection, which they understood as wasteful and inefficient, in favor of an artificial selection that allows humans to control nature through choice to consciously evolve society (Leonard, 2016, p. 103). This study does not delve into Darwin's own thought or whether Wilson's adaptation of Darwin to politics was an accurate or appropriate interpretation. These questions deserve further research. This essay focuses on Wilson's Progressive presentation of Darwin in his argument against the separation of powers.

This note first examines the role of Darwinism in Woodrow Wilson's arguments for administration and Wilson's Darwinist rejection of the separation of powers. It then reviews the continued influence of Darwinism in the public administration literature to demonstrate that the Darwinist sources present at the beginning of the study of administration persist. The note concludes with a brief discussion of the further research needed for a better understanding of the Darwinist roots of modern administration.

\section{Woodrow Wilson and the Darwinian argument for administration}

Woodrow Wilson often employed Darwinian theories in his political writing and rhetoric to argue for an administrative state. Wilson's political thought was influenced by a combination of Edmund Burke, Hegel, and the application of Darwin's biological science to social issues by Herbert Spencer (Pestritto, 2005). Much has been written on Wilson and administration over the decades (Clements, 1998; Cook, 1995, 1998, 2002; Doig, 1983; Kirwan, 1977; Marion, 1980; Martin, 1988; Raadschelders, 2002; Rosenbloom, 2008; Thorsen, 1988). These studies take Wilson's administrative thought seriously, but if they mention Darwin as an element of Wilson's thinking at all, it is only in passing. As noted earlier, the studies on Wilson's influences concentrate on German political thought. Stillman (1973) does note that Wilson was exposed to social Darwinism at Johns Hopkins but never delineates the Darwinian elements of Wilson's argument. Thorsen (1988) mentions Wilson's evolutionary social Darwinism but never develops this idea at length (p. 217). Wilson's indebtedness to Herbert Spencer is recognized by Schulzke (2005), but he ultimately attributes Wilson's political thought to the influence of German historicism. This study does not deny that German thought, especially Hegelianism, was a major influence on Wilson but simply argues that Darwinism was another part of Wilson's argumentation that is often ignored.

Wilson is the focus of this note, as he was a key figure in the development of American public administration 


\section{Darwin and American public administration}

theory. Finding Darwinist elements in Wilson's argument demonstrates that it was present in the early days of American public administration. Of course, Wilson's exact influence on the origins of public administration as a self-conscious discipline is a matter of debate. Van Riper (1984) argues that Wilson's (1887) article on "The Study of Administration" had little to no influence. Other scholarship has challenged this narrative, especially on the grounds that one should focus less on the article's controversial politics-administration dichotomy and more on its broad themes, as well as Wilson's overall effect on public administration (Kirwan, 1987; McCandless \& Guy, 2013). Stillman (1973) concludes that "The Study of Administration" is beset by confusions but is nonetheless important for introducing public administration as its own field of study. For Walker (1989), Wilson was an important figure in the development of public administration as one of the first leading intellectuals in the field and a president who developed the administrative state. According to Pestritto (2007), Wilson's ideas contributed to the work of Frank Goodnow and the New Deal development of an administrative state. Regardless of the debate over the value of "The Study of Administration," Wilson was an important figure in the development of public administration as one of the first to take it seriously as its own field of study.

Engaging in a close reading of Wilson's essential political writings and speeches, one finds that Darwinism was present in his political and administrative thought, especially in his political rhetoric. In his 1912 presidential campaign, as reflected in The New Freedom, Wilson (1913/2005b) often employed the line that government "is accountable to Darwin" (p. 121). Wilson's administrative thought began with an argument against the Constitution's separation of powers that had Darwinian justifications. From Wilson's perspective, the American founders reflected the thinking of their day and crafted a Constitution based on the Newtonian conception of a mechanical universe where checks and balances maintain order and keep every body in its rightful place (Wilson, 1913/2005b, pp. 120-121). Wilson's campaign statements were extrapolations from the argument that he made earlier in his 1908 treatise Constitutional Government. There, Wilson (1908/1974) remarked that Darwin had supplanted Newton as the intellectual source of the era: "in our own day, whenever we discuss the structure or development of anything, whether in nature or in society, we consciously or unconsciously follow Mr. Darwin; but before Mr. Darwin they followed Newton" (p. 105).
With Darwin's conquest of Newton in the public intellectual sphere, his theory could be applied to all elements of life. All theories are derivative of the prevailing scientific discovery of the day. This insight led Wilson (1908/1974) to the proclamation that he would return to in the 1912 campaign:

[G]overnment is not a machine, but a living thing. It falls, not under the theory of the universe, but under the theory of organic life. It is accountable to Darwin, not to Newton. It is modified by its environment, necessitated by its tasks, shaped to its functions by the sheer pressure of life. No living thing can have its organs offset against each other as checks, and live. (p. 106)

Following Darwin, Wilson reconceived government as an organic being. The different branches of government are not universal bodies that hold each other in check, as for Newton, but organs that must grow and work together if the whole political organism is to live and evolve. For Wilson (1908/1974), "governments are living things and operate as organic wholes... . There can be no successful government without leadership or without the intimate, almost instinctive, coordination of the organs of life and action" (pp. 104-106). The separation of powers is an impediment to efficient progress that must be overcome by active government cooperation. The result must be a new conception of constitutional government rooted in Darwinism: "Living political constitutions must be Darwinian in structure and in practice" (Wilson, 1908/1974, p. 106). Wilson conceived of the separation of powers as a negative limitation of government power rooted in Newtonian physics. The separation of powers was cast as an outdated impediment to progress that had to be replaced.

In a 1909 speech on civic problems, Wilson returned to his Darwinian rejection of the separation of powers and explained how checks and balances can be overcome through presidential leadership. There, Wilson (1909/ 1975) struck a familiar chord:

We have been living under an impossible thing,- - a Newtonian system of government. A government is not a mechanism, it is an organism; because it consists of us who are organisms. A government must act by some combined force which is the will of one person, or the will of many persons united; and what we are witnessing now and what we have witnessed under the last two presidents has been 


\section{Benjamin Slomski}

the transformation of our constitution from a Newtonian contrivance, into a Darwinian organism. (p. 84)

The unification of government by one will is a natural development of the evolutionary process as "the leadership of one leading person is Darwinian process. It is the process by which the various organs of a government are being made to either assent or to dissent to some leading series of proposals" (Wilson, 1909/1975, p. 85). Institutional reforms are necessary to reformulate the mechanistic separation of powers into cooperative powers, and presidential leadership is the means to this evolution. A return to Constitutional Government reveals that this presidential leadership cannot occur without a robust administrative state to fulfill the executive duties so that the president is free to act in a political capacity. Given the evolving social problems of the time, it is "becoming more and more true, as the business of government becomes more and more complex and extended, that the President is becoming more and more a political and less and less an executive officer" (Wilson, 1908/1974, p. 113). Therefore, "as legal executive ... the President cannot be thought of alone. He cannot execute laws. Their actual daily execution must be taken care of by the several executive departments and the now innumerable body of federal officials throughout the country" (Wilson, 1908/1974, p. 113). For Wilson, then, the administrative state is essential for overcoming constitutional obstacles and uniting governmental powers. The president must focus on political duties, especially the rhetorical leadership that Wilson (1889/2005a) held as essential for political change. Efficient administration is needed to ensure the effective execution of the laws so that the president is free to engage in unifying political leadership and properly empowered to manage governmental cooperation. If the president is the heart that is necessary for the continued life of the organs of government, then public administration is the arteries the heart depends on.

Given the integral role of public administration in remaking the constitutional order for Wilson, his article on "The Study of Administration" should be read in a new light. Wilson's understanding of public administration is connected to his Darwinist argument for an organic state. Claiming administration was becoming more complex in his time, Wilson (1887) noted that government had to account for the desires of democratic majorities while dealing with the addition of increasing government responsibilities (pp. 200-201). The organic development of America had begun to reach the stage at which the great constitutional questions would be replaced by narrow technical issues.

The two purposes of the study of administration, according to Wilson (1887), are to find the proper functions of government and the means to carry out those functions with the maximum efficiency and the least cost (p. 197). Within the organic state, politics and administration have a complicated relationship. Politics determines the duties for administrators to carry out, but should not interfere in the administrator's decision of how to execute an order (Wilson, 1887, p. 210). Within this political order, administrators have the independent will to select the appropriate means to achieve the ends desired by the political institutions (Wilson, 1887, p. 212). Given the long-standing debate over Wilson's supposed dichotomy between politics and administration, Stillman (1973) suggests that the relationship between politics and administration was not Wilson's focus, as he was more concerned with moral reform of government through administration.

Reform was indeed a major theme for Wilson and was to be accomplished through administrative discretion. Public opinion has an essential role to play as a critic of policy but should avoid interference in the minute specifics of policy implementation as in that field the public is "a clumsy nuisance, a rustic handling delicate machinery" (Wilson, 1887, p. 215). Once Congress has enacted a law, administrators are to be left independent of congressional and public interference as they have the discretion to choose whatever means they deem appropriate to implement a policy. This is a form of organic cooperation between different bodies with different tasks, but also an elevation of administrators, chosen for their scientific expertise, over the political bodies. Only scientific experts possess the knowledge necessary to guide the evolution of society toward specific goals as those who choose the goals lack the skill to actually achieve them.

Wilson dismissed concerns over the irresponsibility of expert administration. The administrative power should not be feared as long as it is responsible, which can be accomplished by giving sufficient power and discretion to department heads and those charged with executing policies so that the people have a clear understanding of who to hold accountable (Wilson, 1887, pp. 213-214). Doubts about whether European models of administrative centralization are compatible with American government were inappropriate for Wilson. Since the goals of administration are everywhere the same, to execute 


\section{Darwin and American public administration}

policy effectively, the practical lessons of European administration can be transplanted to the United States and attached to American constitutionalism, for truly foreign elements cannot grow under this constitutional setting (Wilson, 1887, pp. 218-219). Wilson's conception of the state as an organism alleviated his fears of the incompatibility of German administration with American principles. European practices could be grafted onto the Constitution in a natural manner; the body politic would reject anything incompatible with its natural system, just as the immune system targets viruses. For Wilson, efficient administration is a natural development and a necessary means for the unification of the national government through the executive branch to transform the state from a Newtonian model to a Darwinian organism.

Wilson's administrative thought and practice are now overshadowed by his flagrant racism, with the clearest example being his segregation of the federal bureaucracy (Yellin, 2013). It is possible that Wilson's administrative thought is unrelated to his racism, but it is also possible that Wilson understood his administrative theory and his racism to be part of an organic whole. As Wilson professed his belief in an organic state, minority groups that were seen as less fit or impeding cooperation could be oppressed as a means to social evolution. By conceiving of society as an organism, one reduces individuals to mere cells who find their purpose only within the social whole, and so individual rights lose any validity (Leonard, 2016, p. 102). Wilson was not an isolated case in this era, as evolutionary theories were often employed in defense of racist policies, especially by proponents of race-based eugenics such as Madison Grant and Charles Davenport (see Leonard, 2016, ch. 7). In contrast with the American founders' understanding of citizenship, which held that any individual who accepts the nation's foundational principles can become a citizen, Darwinism bases the capacity for citizenship on group status, including racial characteristics (Marini, 2019, pp. 91-102). Wilson's racism may not have been distinct from his administrative thought, as the notion of an organic state may allow for the oppression of any individuals who do not conform to desires of the organic whole.

One might argue that Wilson's invocation of Darwin was merely political rhetoric and did not reflect any substantial influence on his thought. Admittedly, the foregoing citations are the only references by Wilson to Darwin this author could find. This adds up to six references to Darwin or Darwinism across three different pieces, Constitutional Government, the Civic Problems speech, and The New Freedom. A 1917 diary entry from Secretary of the Navy Josephus Daniels reports that Wilson argued that government is a living organism consistent with Darwin's theory rather than a Newtonian machine during a cabinet meeting (Daniels, 1917/ 1983), so we know that Wilson occasionally made this Darwinian argument from at least Constitutional Government in 1908 to the cabinet meeting in 1917. The evidence shows that Wilson was aware of and interested in evolutionary theory, but it cannot prove how wellread Wilson was in Darwin. The fact, however, that Wilson chose to invoke Darwin in his political rhetoric is significant. Democratic government assumes that rhetoric, the art of persuasion through speech, is essential for politics (Leith, 2016, p. 9). Government by the people is rooted in the necessity of persuading one's fellow citizens for electoral and policy support. Wilson consciously decided to reference Darwin in the 1912 campaign in an attempt to persuade voters to abandon the old conception of a fixed separation of powers in favor of an organic government. At the very least, Wilson thought the citation of Darwin was a persuasive argument in his political time to convince the people of the need for an administrative state.

Wilson employed Darwinism in his rhetoric as a metaphor for government. The metaphorical use of Darwin does not diminish his importance for Wilson, but rather shows that Wilson understood the appeal to Darwin's authority to be a central element of his rhetorical strategy. Scholarship on the importance of rhetoric in politics suggests that metaphor is vital for political argumentation. Walzer (1967) argues that symbolism produces understanding of ideas and unites individuals in a political community. Research in political psychology argues that metaphor is essential for citizens' thinking about politics by providing frames of reference based in existing knowledge (Bougher, 2012; Charteris-Black, 2011; Thibodeau \& Boroditsky, 2011). Emphasizing Wilson's rhetoric is especially appropriate for the 28th president because it connects to the rhetorical presidency literature, which argues that governance through mass popular rhetoric has been a fundamental transformation in the presidency intentionally brought about by Wilson and other Progressives (e.g., Ceaser et al., 1981; Eden, 1996; Tulis, 1987). A deliberate aspect of Wilson's (1889/2005a) argument to replace the separation of powers with an organic government was that popular rhetorical leadership would unite the different branches of government. The Darwinian metaphor was both part of Wilson's argument to jettison the separation of 


\section{Benjamin Slomski}

powers and an example of how Wilson practiced popular rhetoric in his attempt to produce a unified government in rejection of the separation of powers.

\section{Darwinism and contemporary public administration}

One might find the foregoing account to be interesting from a historical perspective but still question whether it has any relevance for contemporary public administration. The Darwinian element of public administration is still felt today, however, wherever efficiency is entrenched as the sole standard for bureaucracy. Standards of efficiency divorced from the separation of powers reflect Wilson's prioritization of efficient administration for social growth. The Darwinist heritage of public administration is also important to understand because it provides greater context to the conscious movement from the past several decades to integrate the insights of evolutionary biology with public administration scholarship (Caldwell, 1980; Masters, 1983; Meyer-Emerick, 2007; Simon, 1996; Smith \& Renfro, 2019). This is most explicit in Gulick's (1977) Wilsonian statement that "the test of the organization is not mechanical, as under the laws of thermodynamics; rather, it is biological, under the evolutionary concepts of Darwin. The proof is survival" (p. 709). This statement corresponds with the rise of sociobiology and biopolitics, two interrelated movements that seek to understand human behavior, including politics, through biological processes (Alford \& Hibbing, 2004; Connolly, 2013; Corning et al., 1999; Hibbing, 2013; Lemke, 2011; Somit \& Peterson, 1999; Wilson, 1975). Even if there has not been much work on the connection of Wilson's administrative thought to Darwin, there has been substantial work employing Darwin, biology, and approaches from the life sciences to the study of public administration and public policy (Blank \& Hines, 2001; Caldwell, 1987; Emmert, 1984; Flohr, 1986; Heinemann \& Lemke, 2014; Liesen, 2007; Losco, 1985; Masters, 1982; Meyer-Emerick, 2004; Mosier, 2019; Schubert, 1988; White \& Losco, 1986). Wilson still has his followers today in those who apply Darwinian biology to administration. Most explicitly, Cook (2010, p. 266), following Wilson, argues that administration is the state's "organ of experience." There is a Darwinian trend within the contemporary literature, but it should not be misunderstood as a new development. Rather, it is a return to Wilson's emphasis on Darwin in the study of administration.

\section{Conclusion}

A full account of the intellectual origins of public administration in the United States should include the role of Darwinism. At the very least, Darwinism complemented German historicism in establishing administrative theory. In the case of Woodrow Wilson, Darwinism provided an argument for reconceiving the state as an organic entity that evolves as social conditions change and offered a metaphor that was at the heart of Wilson's practice of rhetorical leadership in his effort to replace the separation of powers.

This essay hopes to commence a new area of research studying Darwinism's connection to public administration on a theoretical level. This article is a descriptive study examining a particular thinker; more comprehensive studies are needed to trace the broader influence of Darwinism, and normative work is needed to compare the advantages and disadvantages of Darwinist theories of administration. Theoretical and historical work is needed to better understand just how pervasive Darwinism was within early administrative theory. Defenders of the administrative state who were associated with strains of Darwinism, such as Theodore Roosevelt and Oliver Wendell Holmes Jr., as well as Darwinists who opposed the development of an administrative state, such as William Graham Sumner, would provide additional cases to explore. A full account of the development of the administrative state should recognize that some of the leading intellectuals who founded modern public administration had Darwinist elements in their thinking. The theory of the administrative state began in part with the application of evolutionary biology to political life; any theoretical study of the origins of modern administration must reckon with this starting point.

\section{References}

Adams, G. B. (1992). Enthralled with modernity: The historical context of knowledge and theory development in public administration. Public Administration Review, 52(4), 363-373.

Alford, J. R., \& Hibbing, J. R. (2004). The origin of politics: An evolutionary theory of political behavior. Perspectives on Politics, 2(4), 707-723.

Blank, R. H., \& Hines, S. M., Jr. (2001). Biology and political science. Routledge. 


\section{Darwin and American public administration}

Bougher, L. D. (2012). The case for metaphor in political reasoning and cognition. Political Psychology, 33(1), 145-163.

Caldwell, L. K. (1980). Biology and bureaucracy: The coming confrontation. Public Administration Review, 40(1), 1-12.

Caldwell, L. K. (1987). Biocracy: Public policy and the life sciences. Westview Press.

Ceaser, J. W., Thurow, G. E., Tulis, J., \& Bessette, J. M. (1981). The rise of the rhetorical presidency. Presidential Studies Quarterly, 11(2), 158-171.

Charteris-Black, J. (2011). Politicians and rhetoric: The persuasive power of metaphor (2nd ed.). Palgrave Macmillan.

Clements, K. A. (1998). Woodrow Wilson and administrative reform. Presidential Studies Quarterly, 28(2), 320-336.

Connolly, W. E. (2013). Biology, politics, creativity. Perspectives on Politics, 11(2), 508-511.

Cook, B. J. (1995). At the crossroads of the real and the ideal: Woodrow Wilson's theory of administration. Administrative Theory \& Praxis, 17(2), 15-28.

Cook, B. J. (1998). Efficiency, responsibility, and law: Public administration in the early political rhetoric of Woodrow Wilson. Administrative Theory \& Praxis, 20(1), 43-54.

Cook, B. J. (2002). Expertise, discretion, and definite law: Public administration in Woodrow Wilson's presidential campaign speeches of 1912. Administrative Theory \& Praxis, 24(3), 487-506.

Cook, B. J. (2010). The organ of experience: A defense of the primacy of public administrators in the design and reformation of policy and law. Administration \& Society, 42(3), 263-286.

Corning, P., Losco J., \& Wiegele, T. C. (1999). Political science and the life sciences. PS: Political Science and Politics, 14(3), 590-594.

Daniels, J. (1983). From the diary of Josephus Daniels. In A. S. Link (Ed.), The papers of Woodrow Wilson (Vol. 42, p. 343). Princeton University Press. (Original work published 1917)

Darwin, C. (1928). The origin of species by means of natural selection (6th ed.). J. M. Dent \& Sons. (Original work published 1859)

Doig, J. W. (1983). "If I see a murderous fellow sharpening a knife cleverly ...": The Wilsonian dichotomy of the public administration tradition. Public Administration Review, 43(4), 292-304.

Durant, R. F., \& Rosenbloom, D. H. (2017). The hollowing of American public administration. American Review of Public Administration, 47(7), 719-736.
Eden, R. (1996). The rhetorical presidency and the eclipse of executive power: Woodrow Wilson's Constitutional Government in the United States. Polity, 28(3), 357-378.

Emmert, M. A. (1984). Biobehaviorism and small group research. Politics and the Life Sciences, 3(1): 3-10.

Flohr, H. (1986). Teaching biopolitics in Germany. Politics and the Life Sciences, 5(1), 103-112.

Gale, S. A., \& Hummel, R. P. (2003). A debt unpaidReinterpreting Max Weber on bureaucracy. Administrative Theory or Praxis, 25(3), 409-418.

Gulick, L. (1977). Democracy and administration face the future. Public Administration Review, 37(6), 706-711.

Harris, R. (2016). The political development of the regulatory state. In R. Valelly, S. Mettler, \& R. Lieberman (Eds.), The Oxford handbook of American political development (pp. 721-744). Oxford University Press.

Heinemann, T., \& Lemke, T. (2014). Biological citizenship reconsidered: The use of DNA analysis by immigration authorities in Germany. Science, Technology, \& Human Values, 39(4), 488-510.

Hibbing, J. R. (2013). Ten misconceptions concerning neurobiology and politics. Perspectives on Politics, 11(2), $475-489$.

Kettl, D. F. (2000). Public administration at the millennium: The state of the field. Journal of Public Administration Research and Theory, 10(1), 7-34.

Kirwan, K. A. (1977). The crisis of identity in the study of public administration: Woodrow Wilson. Polity, 9(3), 321-343.

Kirwan, K. A. (1987). Woodrow Wilson and the study of public administration: Response to Van Riper. Administration \& Society, 18(4), 389-401.

Liebich, A. (1982). On the origins of a Marxist theory of bureaucracy in the critique of Hegel's "Philosophy of Right." Political Theory, 10(1), 77-93.

Liesen, L. (2007). Women, behavior, and evolution. Politics and the Life Sciences, 26(1), 51-70.

Leith, S. (2016). Words like loaded pistols: Rhetoric from Aristotle to Obama. Basic Books.

Lemke, T. (2011). Biopolitics: An advanced introduction (E. F. Trump, Trans.). New York University Press.

Leonard, T. C. (2009). Origins of the myth of social Darwinism: The ambiguous legacy of Richard Hofstadter's Social Darwinism in American thought. Journal of Economic Behavior and Organization, 71(1), 37-51. 


\section{Benjamin Slomski}

Leonard, T. C. (2016). Illiberal reformers: Race, eugenics, of American economics in the Progressive Era. Princeton University Press.

Losco, J. (1985). Evolution, consciousness, and political thinking. Political Behavior, 7(3), 223-247.

Marini, J. (2019). Unmasking the administrative state: The crisis of American politics in the twenty-first century (K. Masugi, Ed.). Encounter Books.

Marion, D. E. (1980). Alexander Hamilton and Woodrow Wilson on the spirit and form of a responsible republican government. Review of Politics, 42(3), 309-328.

Martin, D. W. (1988). The fading legacy of Woodrow Wilson. Public Administration Review, 48(2), 631-636.

Masters, R. D. (1982). Is sociobiology reactionary? The political implications of inclusive-fitness theory. Quarterly Review of Biology, 57(3), 275-292.

Masters, R. D. (1983). The biological nature of the state. World Politics, 35(2), 161-193.

Mayr, E. (2000). Darwin's influence on modern thought. Scientific American, 283(1), 78-83.

McCandless, S. A., \& Guy, M. E. (2013). One more time: What did Woodrow Wilson really mean about politics and administration? Administrative Theory \& Praxis, 35(3), 356-377.

Meyer-Emerick, N. (2004). Biopolitics, dominance, and critical theory. Administrative Theory \& Praxis, 26(1), 1-15.

Meyer-Emerick, N. (2007). Public administration and the life sciences: Revisiting biopolitics. Administration \& Society, 38(6), 689-708.

Moreno, P. D. (2013). The American state from the Civil War to the New Deal: The twilight of constitutionalism and the triumph of progressivism. Cambridge University Press.

Mosier, S. L. (2019). Policies as species: Viewing and classifying policy from an evolutionary biology perspective. Politics and the Life Sciences, 38(2), 117-131.

Paul, D. B. (2009). Darwin, social Darwinism, and eugenics. In J. Hodge \& G. Radick (Eds.), The Cambridge companion to Darwin (2nd ed., pp. 219-245). Cambridge University Press.

Pestritto, R. J. (2005). Introduction. In R. J. Pestritto (Ed.), Woodrow Wilson: The essential political writings (pp. 1-27). Lexington Books.

Pestritto, R. J. (2007). The progressive origins of the administrative state: Wilson, Goodnow, and Landis. Social Philosophy \& Policy, 24(1), 16-54.

Raadschelders, J. C. N. (2002). Woodrow Wilson on the history of government: Passing fad or constitutive framework for his philosophy of governance? Administration \& Society, 34(5), 579-598.

Rosenbloom, D. H. (2008). The politics-administration dichotomy in U.S. historical context. Public Administration Review, 68(1), 57-60.

Rosser, C. (2010). Woodrow Wilson's administrative thought and German political theory. Public Administration Review, 70(4), 547-556.

Rosser, C. (2012). Examining Frank J. Goodnow’s Hegelian heritage: A contribution to understanding progressive administrative theory. Administration \& Society, 45(9), 1063-1094.

Sager, F., \& Rosser, C. (2009). Weber, Wilson, and Hegel: Theories of modern bureaucracy. Public Administration Review, 69(6), 1136-1147.

Schubert, J. N. (1988). Age and active-passive leadership style. American Political Science Review, 82(3), 763-772.

Schulzke, C. E. (2005). Wilsonian crisis leadership, the organic state, and the modern presidency. Polity, 37(2), 262-285.

Seibel, W. (2010). Beyond bureaucracy-Public administration as political integrator and non-Weberian thought in Germany. Public Administration Review, 70(5), 719-730.

Shaw, C. K. Y. (1992). Hegel's theory of modern bureaucracy. American Political Science Review, 86(2), 381-389.

Simon, H. A. (1996). Models of my life. MIT Press.

Smith, K. B., \& Renfro, J. L. N. (2019). Darwin's bureaucrat: Reassessing the microfoundations of bureaucracy scholarship. Politics and the Life Sciences, 38(2), 168-179.

Somit, A., \& Peterson, S. A. (1999). Rational choice and biopolitics: A (Darwinian) tale of two theories. PS: Political Science and Politics, 32(1), 39-44.

Spicer, M. W. (2004a). Note on origins: Hegel, Weber, and Frederician Prussia. Administrative Theory \& Praxis, 26(1), 97-102.

Spicer, M. W. (2004b). Public administration, the history of ideas, and the reinventing government movement. Public Administrative Review, 64(3), 353-362.

Stillman, R. J., II. (1973). Woodrow Wilson and the study of administration: A new look at an old essay. American Political Science Review, 67(2), 582-588.

Thibodeau, P. H., \& Boroditsky, L. (2011). Metaphors we think with: The role of metaphor in reasoning. PLOS ONE, 6(2), e16782.

Thorsen, N. A. (1988). The political thought of Woodrow Wilson, 1875-1910. Princeton University Press. 


\section{Darwin and American public administration}

Tijsterman, S. P., \& Overeem, P. (2008). Escaping the iron cage: Weber and Hegel on bureaucracy and freedom. Administrative Theory \& Praxis, 30(1), 71-91.

Tulis, J. K. (1987). The rhetorical presidency. Princeton University Press.

Van Riper, P. P. (1984). The politics-administration dichotomy: Concept or reality? In J. Rabin \& J. S. Bowman (Eds.), Politics and administration: Woodrow Wilson and public administration (pp. 203-218). Marcel Dekker.

Walker, L. (1989). Woodrow Wilson, progressive reform, and public administration. Political Science Quarterly, 104(3), 509-525.

Walzer, M. (1967). On the role of symbolism in political thought. Political Science Quarterly, 82(2), 191-204.

White, E., \& Losco, J. (Eds.). (1986). Biology and bureaucracy: Public administration and public policy from the perspective of evolutionary, genetic, and neurobiological theory. University Press of America.

Wilson, E. O. (1975). Sociobiology: The new synthesis. Belknap Press of Harvard University Press.
Wilson, W. (1887). The study of administration. Political Science Quarterly, 2(2), 197-222.

Wilson, W. (1974). Constitutional government in the United States. In A. S. Link (Ed.), The papers of Woodrow Wilson (Vol. 18, pp. 69-216). Princeton University Press. (Original work published 1908)

Wilson, W. (1975). Civic problems. In A. S. Link (Ed.), The papers of Woodrow Wilson (Vol. 19, pp. 81-97). Princeton University Press. (Original work published 1909)

Wilson, W. (2005a). Leaders of men. In R. J. Pestritto (Ed.), Woodrow Wilson: The essential political writings (pp. 211-229). Lexington Books. (Originally given as a speech in 1889)

Wilson, W. (2005b). The new freedom. In R. J. Pestritto (Ed.), Woodrow Wilson: The essential political writings (pp. 107-123). Lexington Books. (Original work published 1913)

Yellin, E. S. (2013). Racism in the nation's service: Government workers and the color line in Woodrow Wilson's America. University of North Carolina Press. 